\title{
HIBERNIA, HOUSING AND HEALTH: SOME IMPACTS OF OFFSHORE OIL DISCOVERY ON AN URBAN HOUSING MARKET
}

\author{
MARK SHRIMPTON \\ City of St. John's \\ Newfoundland \\ and \\ JANE LEWIS \\ London School of Economics
}

\begin{abstract}
Predicting the responses to the possible development of oil in the Hibernia field is complicated by many uncertainties. The experience of Aberdeen and Calgary are not sufficiently similar to provide good demographic comparisons. The technology of the oil and gas industry is subject to rapid change and the particular geology and geography of Hibernia introduce added uncertainties. Nevertheless, the expectation of development has had, and continues to have, major effects on St. John's, Newfoundland, with particular impacts on the housing market.
\end{abstract}

The principal concern of this paper is with the individual, communal and corporate responses to the expectation that Hibernia and other of fshore oil and gas fields of Newfoundland will be developed and especially with the impact of these responses on the city of St, John's and its housing market.

Thus, unlike other presentations concerned with classic resource based communities, this paper considers the impact of resource development prospects on an existing large urban area in which less than $2 \%$ of the labour force are presently engaged in primary industry, St. John's, with a 1981 population of
155,000 , is the second largest and fastest
growing growing metropolitan area in Atlantic Canada, containing $27 \%$ of Newfoundland's population and $39 \%$ of its employed labour force. It is the main centre of government, business, education, retailing, distribution and light industry in the province. Indeed, it is these urban characteristics, rather than the fact that St. John's has the closest harbour and airport to the Hibernia area, that seem likely to draw oil-related activity to the city. For while a major theme of this paper is the high degree of uncertainty about prospective impacts, evidence from other areas subject to similar developments shows employment creation concentrated in major urban areas,* with these new jobs spread throughout the urban economy rather than concentrated in construction or resource extraction activities. St. John's can expect an acceleration of existing urban growth trends rather than the

- For instance, in 1981 the Aberdeen area, which contains no major platform construction yards or oil refineries, and which is increasingly remote from new offshore developments, accounted for $58 \%$ of oilrelated employment in Scotland. 
superimposition of a radical new form of growth. Thus any consideration of the psycho-social impacts of the possible development of Hibernia and other fields is in part concerned with the impacts of urbanization, per se,

The relationship between urbanization and mental health has been considered by Lord Stephen Taylor, Sydney Chave, Leo Srole and others. Many early studies of urbanization were highly critical of its impact on physical welfare ("urban degeneration") and social relations and argued that such factors led to mental stress. However, Srole clearly believes in David Donnison's "The Good City" $\mathrm{y}^{\prime \prime}$ that is, he rejects the idea that cities are either inherently bad or are bad as they are, although he believes that they need regulation and planning. If this is accepted, the issue then becomes: what criteria should planners use? To build better communities is all very well, but community is a notoriously nebulous concept. The planner may put in community bealth centres, ete., but the success of such centres in Canada is in doubt for reasons which may have little to do with urban planning and a lot to do with the health profession. However such a discussion takes us beyond the focus of this symposium and the scope of this paper.

\section{ASSESSING THE IMPACTS- THE PROBLEMS OF UNCERTAINTY}

The Hibernia P-15 discovery in late 1979 had clear implications for the province in terms of both resource revenues and economic growth, and it was soon apparent that St. John's would see much of the impact. There developed a two-sided vision of opportunities and threats, including the creation of new business and employment, an influx of outsiders, rapid urban growth, more high-rise office and apartment buildings, soaring housing and other costs, social problems and the destruction of existing lifestyles. Responses to these expectations have been numerous and varied, reflecting the particular interests of the individuals and groups involved, the degree of economic and political power they wield, and their perceptions of the likely impact of petroleumrelated development.

Initially there was an attempt to study the experiences of other cities subject to similar developments-principally Aberdeen, Stavanger and Calgary and to draw on the existing literature on these experiences. Lan. guage problems clearly limited use of the Norwegian approach to offshore development. This obviously introduced an early bias into local perceptions of, and attitudes towards, potential impacts in Newfoundland.

Later fact-finding trips helped Newfoundlanders to put the experience of other areas in context and to further their understanding of the impacts of offshore developments. However, in many cases, the principal objective of these trips was promoting economic development, and any evaluation of broader social impacts was incidental to this.

Three factors explain the early reliance on the experiences of other cities: lack of experience with assessing the impacts of such developments and the consequent shortage of relevant expertise; a shortage of baseline data and studies of Newfoundland in general and St. John's in particular; and the uncertainty that is characteristic of offshore oil and gas development.

At the time of Hibernia, the number of people engaged in social scientific research in Newfoundland was limited and they were mainly associated with Memorial University of Newfoundland. However, research at Memorial was mostly concerned with rural Newfoundland and its unique social, cultural and economic patterns, with St. John's generally regarded as being just another North American city. Similarly research being undertaken by the provincial government consisted principally of economic analyses of proposed resource developments located in rural Newfoundland, commonly using costbenefit methods. 
Recognition of the uncertainties associated with such offshore developments may have been one of the more important advances in the evolution of local approaches towards the evaluation of the social and economic impacts of Hibernia. Begg and Newton (1980) have noted that:

"The planning problems associated with oil and gas-related developments are complex, technically difficult and on a scale not before experienced in Scotland. Furthermore, the technology of the industry itself is subject to rapid change. Central Government poiticy is continually evolving and the attitudes of developers remain largely unknown. In such circumstances where neither the amount of the resource available nor the timing of its exploitation are certain, there are found to be difficulties in predicting the nature, spatial requirement and timing of associated land-use planning developments,"

Environmental, technological, economic and political uncertainties, which are characteristic of offshore petroleum development in general, are exacerbated in Newfoundland by local factors-the complex geology of the Hibernia field and the seasonal presence of icebergs on the Grand Banks-both of which affect the economic viability of the field.

Clearly these uncertainties about whether, when and/or how Hibernia might be developed complicate any attempts to assess the implications for the City of St. John's. Construction of a pipeline would, for instance, require a relatively large local labour force and throughput of materials, as well as onshore trans-shipment, pipe-coating and other facilities. Such activity might well be centered on St. John's. If shuttle tankers are used to ship the oil, however, they would likely be built outside the Province, and their Operation would have minor impact on the region.

\section{DEMOGRAPHIC IMPACT}

These uncertainties are further multiplied when attempts are made to estimate regional population growth. To date, no projection of the overall demographic impact of Hibernia has been attempted, although the Mobil Oil Environmental Impact Assessment Group at Memorial University have produced some necessarily tentative figures (Stoney and Shrimpton, 1981). The figures they have produced can only be viewed as an indication of the order of magnitude of the demographic impact.

The demand for land, housing, retailing. industrial parks, regional infrastructure, and social services are all to a greater or lesser degree secondary to the amount of population growth. In the St, John's region past trends often no longer apply, while the uncertainty associated with the petroleum industry limits the use of the experience of other cities. Local researchers or planners producing or using population forecasts clearly have to be very circumspect and emphasize uncertainties, probabilities, perceptions and estimates.

\section{TIMING OF THE NEWFOUNDLAND DEVELOPMENT}

The discussion above focuses largely on the Hibernia field and ignores uncertainties about the existence and economic viability of other fields, and the possible timing of their development. Generally speaking, simultaneous development best meets federal objectives through a rapid movement to national energy self-sufficiency and a reduction in the relative importance of Albertan oil. Phased development would accord with provincial desires to maximize local economic benefits and minimize the danger of a "boom-bust" scenario. Such policy differences further increase uncertainty about the prospective impact of oil-related developments in the province, given the unresolved issue of jurisdiction over the offshore.

\section{RESPONSE TO UNCERTAINTY- POPULATION AND HOUSING}

All these uncertainties have not precluded a wide range of private and public sector 
responses to Hibernia. However, much of this speculation may have been unproductive or counter-productive, for a failure or inability to use more sophisticated analyses has often led to a reliance on the simplistic application of information gleaned from other cities. In many cases, the experiences of such cities have been both misperceived and misapplied. The rest of this paper illustrates this point with respect to population growth and changes in the housing market.

Aberdeen had been subject to rapid population growth as a result of offshore oil developments, and as early as 1974 Aberdonian local government officials were warning that St. John's should be prepared for similar increases (Russell, 1977). The Aberdonian petroleum consultant hired by the city of St. John's for a few months in early 1980 stressed the same point. Similarly Mayor Ralph Klein of Calgary, reported in the St. John's Evening Telegram (1981), suggested that St. John's, one-third the size of Calgary, could expect in-migration at one-third the Calgary rate, or about a thousand people a month. From this he predicted soaring construction rates and house prices and increases in suicides, divorces and crime. On the basis of such types of speculation, letters to local papers called for the arming of the Royal Newfoundland Constabulary. (As a matter of interest the crime rate in the Aberdeen Area declined relative to that for the rest of Scotland during the 19705.)

However, examination of population data for Aberdeen and Calgary shows a misperception of the growth in the former case, and a misapplication of the growth to the St. John's case in the latter. Census statistics for the Aberdeen area show that between 1951 and 1971 the population had increased by only $3.3 \%$ and between 1971 and 1976 (Aberdeen's "Hibernia" was in 1969), there was a population increase of only $2.5 \%$. During the same five year period, unassisted by oil developments the population of metropolitan St. John's increased by nearly $9 \%$, or more than three times as rapidly.
Thus, Aberdeen saw a change from an essentially static to a dynamic demographic growth picture while St. John's has long been a rapidly growing urban area. This high St. John's growth rate has required a continuous provision of new housing, office and retail space, industrial sites, regional infrastructure and expanded social services, and the public and private sectors have evolved with the capability to satisfy this requirement.

There is no doubt that Calgary experienced very rapid rates of population increase. However, there are various reasons for rejecting Calgary as a model for what will occur in St. John's. Such growth resulted from coincidental rapid natural and migratory increases, while in St. John's in-migration will to some degree be replacing declining natural increase. The volume of such in-migration may be smaller than in Calgary because the offshore oil industry is less labour-intensive than its onshore counterpart and because, while Alberta has labour shortages, Newfoundland has a significant surplus. Lastly, much of Calgary's growth can be attributed to its development as the capital of Canada's oil industry. Clearly St, John's will not usurp that role, and it is unlikely to perform more than regional headquarters functions. It appears unlikely that there will be any "population explosion" in St. John's although such an expectation is still widespread in the community.

The housing market provides an interesting exchange of the significance of such expectations, In the four months after the announcement of the Hibernia discovery, new house prices in St. John's rose by almost ten percent, compared with a total increase of only five percent of the previous thirty-six months (Statistics Canada, 1980). In the year after Hibernia the price of existing houses jumped by over twenty percent (Royal Trust. 1980). These increases were not in line with regional or national trends, and were largely the result of speculation surrounding Hibernia. They cannot be explained by the (relatively small) number of new oil industry 
employees who moved to the city. Similarly, there was no shortage of land for residential development, while land ownership was fragmented with no single private owner controlling more than eight percent of developable land (C.M.H.C, 1981A).

Instead, the main cause of the increase was likely the response of large numbers of individuals and groups to the expectation that property prices would rise rapidly, as had been the case in Aberdeen, Stavanger, and Calgary and as had been prophesied by Mayor Klein and others. It is a classic case of a self-fulfilling prophecy, the result of the independent speculative actions of a wide range of individuals and groups.

As fewer families have been able to afford to own a house, the demand for apartments and other rental units has increased. Canada Mortgage and Housing Corporations (C.M.H.C.) forecast that over the next five years about eight thousand new households will be entering the St. John's housing market looking for homes (C.M.H.C., 1981B).

The rental sector is poorly developed in St. John's, accounting for less than a third of all dwellings. This is the lowest proportion for any Canadian metropolitan area, and it would be significantly lower if St. John's did not have relatively large numbers of public housing units, for they account for a quarter of all rental accommodations. It is difficult to get good data on rent increases because of limited size of this sector, but C.M.H.C. figures show that in the two years after the Hibernia discovery, the rent for the cheapest two-bedroom units in apartment buildings rose by $35 \%$ (where heat and light was not included), and by $49 \%$ (where it was) (C.M.H.C. unpublished data),

The rents of existing units are to some degree regulated by the provincial Residential Tenancies Board. New units are not subject to such control and hence their apartments coming onto the market in 1977 had an average rent of $\$ 275$ a month, while by 1982 this had risen to $\$ 585$ (C.M.H.C. unpublished data), In the two years before Hibernia the increase averaged seven percent a year; in the three years since Hibernia the annual increase had averaged twenty-three percent. However, this reflects factors other than the impact of offshore discovery, chief among them being increases in mortgage rates.

Since 1980 there has been a slump in house construction, and house costs have risen sharply. As a result the housing choices of low and middle income households are increasingly limited and more and more of their income is going to pay for basic shelter. Furthermore, there has been a loss of cheaper housing in the inner city through the deterioration and condemnation of older houses, the encroachment of commercial developments and, to some extent, gentrification, while the number of unemployed and underemployed has increased. It is little wonder that increasing numbers of people are having to turn to public housing.

In 1981 the Newfoundland and Labrador Housing Corporation (N.L.H.C.) received about twenty new applications for public housing each week but this rose to thirty a week in 1982. According to the Newfoundland and Housing Corporation (1982) at this rate there will be over fifteen hundred new applicants in 1982, while by March 1982 there were already 581 families on the waiting list. C.M.H.C. estimates that only about one hundred new public housing units will be built in 1982, and N.L.H.C. have calculated that in the first half of the year new demands for their units will exceed supply by about four hundred families.

\section{CONCLUSIONS}

This paper has described and discussed the impact of the prospective development of a major offshore resource, the Hibernia oil and gas field, on the nearest major urban area, St. John's. The emphasis has been on the causes and consequences of community expectations as to this impact, illustrated by reference to recent changes in the St. John's 
housing market. A number of other examples could have been used (Shrimpton, 1982) but none has been quite as dramatic or has had such a direct impact on St. John's residents.

A deliberate attempt has been made to avoid trying to predict the actual impact should Hibernia be developed. In our current attempts to forecast the impacts it sometimes seems that the only certainty is uncertainty (although there has in fact been a slow qualitative and quantitative improvement in our knowledge). However, in conclusion, it should be noted that the evidence from Aberdeen and Stavanger suggests that the overall impact of oil and gas development on St. John's will be largely beneficial. Each has had significant problems (for instance, those on fixed incomes have been particularly vulnerable to cost of living increases), but there has been substantial growth in employ. ment and improvement in the standard of living and quality of life. It would be ironic if, in St. John's, much of this benefit were negated by ill-conceived speculative responses based on misperceptions of, and the misapplications of, the experience of these cities.

\section{RÉSUMÉ}

Il est difficile de prévoir les répercussions de l'exploitation du champ pétrolifére Hibernia en raison des nombreux impondérables liès à ce type de projet. Les expériences d'Aberdeen et de Calgary sont trop différentes pour servir de base de comparaison sur le plan démographique. La technologie utilisée par l'industrie pétrolifere et gazière progresse trés rapidement, et les caractéristiques géologiques et géographiques particulières de Hibernia ajoutent d'autres incertitudes. Néamoins, la possibilité d'une exploitation éventuelle de ce champ pétrolifere a eu et continue d'avoir des effets importants sur St-Jean, Terre-Neuve, notamment sur le marché immobilier.

\section{REFERENCES}

Begg, $H$, and Newton, K. Strategic planning for oil and gas development. Town Planning Review, Vol. \$1, No. 1, 1980.

Central Mortgage and Housing Corporation. Land and Infrestructure Mapping Study: St. John's. Ottawa, 1981(A).

Central Mortgage and Housing Corporation. Imipoct of Petroleum Developmient on the Local Housing Markef. Paper presented at the Planning for Petroleum Conference. St. John's, September. $1981(B)$.

Royal Trust "'Survey of Canadian House Prices," Toronto: 1980 .
Russell, L. A Scottish Local Authority Viewpoint in Mt J Scarlett (Ed.), Conseypaences of offshiore oil and gax-Norway. Scotland and Newfotandland, Insttute of Social and Economic Research, Memorial University of Newfoundland, St. John's, 1977.

Shrimpton, M. Assessing the impacts of offshore oil an the St. John's Metropolitan Area (paper presented at the 2nd International Conference on Oit and the Environment), Halifax, August, 1982.

Statistics Canada, Construction price staristics, catalogue 62-007, Ottawa: 1980.

Storey, K. and Shrimpton, M. Demographic implicutions of Hibernia (mimeo). Paper presented at the Planning for Petrolean Conference. St. John's, 1981 